\title{
UJI HISTOLOGI UDANG PUTIH (Liptopenaeus vannamei) SELAMA PENYIMPANAN PADA SUHU RENDAH
}

\section{White Shrimp (Liptopenaeus vannamei) Histologi Analysis During Storage at Low Temperature}

\author{
Dion Mayodra ${ }^{1}$,Fitra Mulia Jaya ${ }^{2 *}$, Tri Widayatsih ${ }^{3}$ \\ ${ }^{1}$ Program Studi Ilmu Perikanan Universitas PGRI Palembang \\ ${ }^{2}$ Program Pascasarjana Universitas PGRI Palembang \\ *corresponding author : f_Muliajaya@yahoo.co.id
}

\begin{abstract}
ABSTRAK
Salah satu hasil tangkapan penduduk di Desa Sungsang adalah udang. Hasil tangkapan para nelayan di desa Sungsang didistribusikan ke perusahan pembekuan udang atau ikan melalui pos-pos perwakilan yang ada di Desa Sunsang. Selain itu, udang juga didistribusikan ke wilayah Kabupaten Banyuasin dan Palembang dengan waktu tempuh 2,53 jam. Ketika sampai di Palembang, terkadang udang bekukan terlebih dahulu sebelum dibawa ke pasar untuk didistribusikan ke konsumen Seperti kita ketahui bahwa udang merupakan hasil perikanan yang mudah mengalami kemunduran mutu. Oleh karena itu, peneliti bertujuan untuk mengetahui keadaan struktur sel dan jaringan tubuh udang yang didistribusikan dari Desa Sungsang dengan melalui uji Histologi. Udang yang akan di amati yaitu udang yang ditransportasikan dengan suhu $4^{\circ} \mathrm{C}$ dan selanjutnya dilakukan penyimpanan pada suhu tersebut. Pengamatan dilakukan sampai hari 12 hari dengan interval hari ke-0,ke-3, ke-6, ke-9 dan hari ke-12. Penelitian ini dilakukan pada bulan April hingga bulan Mei. Hasil uji Histologi menunjukkan bahwa struktur jaringan tubuh daging udang sudah mulai merenggang pada hari ke-3 sampai hari ke-12.
\end{abstract}

Kata Kunci: Udang, penyimpanan, suhu rendah

\begin{abstract}
Sungsang Village is one of the villages in the Banyuasin District of South Sumatra bordering the Bangka sea so that the potential for fishery products is very high. One of the catches of the population in the area is shrimp. The catches of fishermen in the village of Sungsang are distributed to shrimp or fish freezing companies through representative posts in the Sunsang Village. In addition, shrimp are also distributed to the Banyuasin and Palembang regencies with a travel time of 2.5-3 hours. When he arrived in Palembang, sometimes the shrimp freeze before being brought to the market to be distributed to consumers. As we know that shrimp is the result of fisheries that are prone to deterioration in quality. Therefore, researchers aimed to determine the state of cell structure and body tissue of shrimp that were distributed from Sungsang Village through Histology tests. Shrimp that will be observed are shrimps transported at $4^{\circ} \mathrm{C}$ and then stored at that temperature. Observations were carried out until the 12th day at intervals of days $0,3 \mathrm{rd}$, 6th, 9th and 12th day. This research was conducted in April until Mei. The results of the Histology test showed that the structure of the body tissue of shrimp meat on day 3 began to stretch until the 12th day.
\end{abstract}

Keywords: Shirmp, storage, low tempaerature 


\section{PENDAHULUAN}

Udang adalah komoditas perikanan andalan Indonesia yang menjadi komoditas ekspor. Terdapat beberapa jenis udang yang banyak dipelihara petambak di Indonesia, yaitu udang windu, udang vaname, udang api-api, udang putih, dan udang galah. Udang budidaya yang dikaitkan dengan pasar ekspor Indonesia adalah udang windu dan udang vaname, sedangkan jenis udang lainnya digunakan untuk keperluan pasar dalam negeri salah satunya adalah udang putih (Kementerian Perdagangan, 2013).

Sektor kelautan dan perikanan khususnya di Provinsi Sumatera Selatan merupakan salah satu sektor yang mempunyai potensi yang cukup besar khususnya sektor budidaya, sehingga mampu mensejahterkan masyarkat pelaku perikanan. Wilayah pesisir timur Sumatera Selatan memiliki potensi budidaya udang yang tinggi (KKP, 2020).

Salah satu Kabupaten yang mempunyai potensi hasil tangkapan udang yang cukup tinggi adalah Banyuasin tepatnya di desa Sungsang karena hampir separuh penduduk desa Sungsang mempunyai mata pencaharian nelayan tangkap yang beroperasi di laut sungai Sembilang sampai ke selat Bangka Belitung. Wilayah pemasaran hasil tangkapan tersebut tersebar ke beberapa wilayah khususnya Kota Palembang (Jaya dkk. 2018).

Udang merupakan produk pangan hasil perikanan yang mudah mengalami kerusakan dan kemunduran mutu (perishable food) serta mempunyai umur simpan yang singkat. Proses kemunduran mutu udang dapat disebabkan oleh adanya reaksi autolisis yaitu dapat dipengaruhi oleh adanya aktivitas enzim, aktivitas bakteri, dan reaksi kimiawi pada saat penyimpanan, namun yang menjadi kendala dalam pemenuhan permintaan udang yaitu masalah konsistensi mutu udang (Suwetja, 2011 dalam Laila, 2015).

Kemunduran mutu pada udang sangat erat kaitannya dengan melanosis atau blackspot dan mikroba pembusuk (Gokoglu dan Yerlikaya 2008). Pembentukan melanosis atau blackspot merupakan perubahan warna yang terjadi karena adanya reaksi enzimatis oleh enzim polyphenoloxidase. Pembentukan melanosis atau blackspot dapat mempengaruhi parameter warna dan mempengaruhi penerimaan konsumen (Kim et al., 2000).

Laju penyebaran blackspot pada udang akan bertambah seiring dengan lama waktu penyimpanan. Penyebaran blackspot ini dapat dijadikan parameter dalam kemunduran mutu udang (Utari, 2014). Selain itu, faktor fisik juga sangat mempengaruhi terhadap laju kemunduran mutu udang, seperti benturan, tekanan, dan goresan. Udang yang terlalu banyak mengalami kontak atau benturan fisik akan lebih cepat mengalami pembusukan (Nurjanah et al., 2011).

Mengingat waktu tempuh desa Sungsang ke Kota Palembang cukup lama yaitu 3 sampai 3,5 Jam, sehingga perlu diketahui bagaimana konsistensi udang yang ditransportasikan selama waktu tersebut. Penelitian mengenai kemunduran mutu udang telah banyak dilakukan. Pornrat et al., (2007) mengamati perubahan tekstur dan struktur udang galah (Macrobrachium rosenbergii) pada suhu 5 ${ }^{\circ} \mathrm{C}$ selama 14 hari penyimpanan dan hasil dari pengamatan tersebut menunjukkan terjadi perubahan struktur mikroskopik pada miofibril selama waktu penyimpanan. Zamorano et al., (2009) mengamati penyebaran melanosis pada pink shrimp (Parapenaeus longirostris) pada suhu $4{ }^{\circ} \mathrm{C}$ selama waktu penyimpanan dan hasil dari pengamatan tersebut menunjukkan bahwa kecepatan penyebaran blackspot paling tinggi terjadi pada karapas udang . Informasi mengenai analisis tingkat kemunduran mutu udang putih (Litopenaeus vannamei) berdasarkan lama penyimpanan pada suhu rendah masih sedikit sehingga diperlukan penelitian ini untuk mengetahui mutu udang yang segar. 


\section{METODE PENELITIAN \\ Waktu dan Tempat}

Penelitian ini dilaksanakan pada bulan Februari hingga bulan April yang dilakukan di Workshop TPHP Kampus C Universitas PGRI Palembang, Balai Karantina Ikan, Pengendalian Mutu dan Keamanan Hasil Perikanan (BKIPM) Kelas II Palembang dan analisa kimia di lakukan di Laboratorium Kimia dan Mikrobiologi Hasil Pertanian Universitas Sriwijaya, Sumatera Selatan.

\section{Bahan Penelitian}

Bahan yang digunakan dalam penelitian ini adalah Udang Putih (Litopenaeus vannamei) 40 ekor, 10-13 gram/ekor, Buffer Normal Formalin (BNF), Alkohol, Xylol, Davidson.

Adapun alat yang digunakan dalam penelitian ini yaitu meliputi : Cool box, Refrigerator, Score sheet, Pisau scalpel, Objek dan deck glass, Mikroskop, Kasa, cawan petri, timbangan elektrik, thermometer, gunting, botol film pipet volumetrik, plastik bening dan lain-lain.

\section{Metode Penelitian}

Metode Pengumpulan Data dalam Penelitian ini adalah :

1) Pengumpulan data primer, yaitu dilakukan dengan cara melakukan kegiatan penelitian dan pengamatan secara langsung meliput uji histologi.

2) Pengumpulan data sekunder, yaitu data yang diperoleh dari penelitian dan buku-buku, jurnal, dan skirpsi untuk melengkapi data yang diperoleh dari seluruh kegiatan (Sugiyono,2018).

3) Dokumentasi, yaitu pengambilan gambar langsung mengenai semua kegiatan dalam penelitian untuk melengkapi lampiran yang diperoleh dari seluruh kegiatan penelitian.

\section{Prosedur kerja}

Udang Putih (Litopenaeus vannamei) disimpan pada suhu chilling $\left(4^{\circ} \mathrm{C}\right)$ selama 14 hari menggunakan
Refrigerator (kulkas), sebelum disimpan udang di timbang, sampel udang sebanyak 40 ekor, berat seragam berkisar 10-13 gram/ ekor. Dilakukan pengamatan pada hari ke -0 , ke -3 , ke -6 , ke -9 , dan pada hari ke- 12, pengamatan meliputi jaringan udang dengan uji Histologi. Pengamatan udang dilakukan untuk melihat konsistensi udang.

\section{Preparasi dan Transportasi Sampel}

Preparasi merupakan suatu kegiatan penanganan ikan setelah ditangkap. Preparasi bertujuan untuk mempermudah dalam pengolahan dan mengetahui rendemen dari bagian yang diambil.

Penelitian ini menggunakan udang segar, udang putih (Litopenaeus vannamei) diperoleh dari supplier di Desa Sungsang, Kabupaten Banyuasin, Sumatera Selatan dalam keadaan mati. Udang ditransportasikan dari Sungsang hingga Palembang dengan mempertahankan suhu $4{ }^{\circ} \mathrm{C}$, udang ditransportasikan dengan sistem kering yaitu pengangkutan udang menggunakan peti es (cool box) dengan penambahan es sebagai media secara tertutup.

\section{Penyimpanan Sampel}

Udang Putih (Litopenaeus vannamei) yang digunakan pada penelitian ini disimpan pada suhu chilling $\left(4{ }^{\circ} \mathrm{C}\right)$. Udang disimpan pada wadah tertutup selama 12 hari menggunakan Refrigerator (kulkas). Dilakukan Analisa Jaringan (Histologi) dilakukan pada hari ke-0, ke-3, ke-6, ke-9, dan ke-12 pada sampel.

\section{Analisa Data}

Data yang diperoleh dari pengamatan disajikan dalam bentuk gambar sehingga memberikan gambaran jelas penelitian mengenai konsistensi jaringan tubuh udang selama mengalami kemunduran mutu pada suhu rendah $4^{\circ} \mathrm{C}$. Metode analisis yang digunakan dalam penelitian ini yaitu lain data hasil uji histologi di analisa secara deskriptif. 


\section{HASIL DAN PEMBAHASAN}

Salah satu kemunduran bahan pangan bisa diketahui melalui pengamatan histologi. Pengamatan dilakukan menggunakan bagian abdomen udang berupa daging dan karapas udang yang dipotong secara membujur. Serabut otot pada udang terbagi menjadi dua yaitu otot longitudinal dan otot transversal. Menurut Prasetyani (2017), Pembuatan preparat histologi dapat dilakukan berdasarkan prosedur sebagai berikut: fiksasi, dehidrasi, penjernihan, impegnasi, blocking, pemotongan block, floating serta perwarnaan.

Histologi adalah ilmu yang mempelajari jaringan sel dalam tubuh menggunakan metode kimia dan analitik mikroskopik (Harjana, 2011) Analisa histologi dapat menjadi parameter yang sangat sensitif dan menjadi sangat penting didalam menentukan perubahan struktur sel yang terjadi di organ dalam seperti ginjal, hati dan gonad (Dutta, 1996 dalam Khaisar, 2006). Adapun hasil uji Histologi pada Udang Putih (Liptopenaeus vannamei) selama penyimpanan sebagai berikut :

\section{Uji Histologi Hari ke-0}

Pada sampel udang hari ke-0 (H0) lapisan otot lateral dan serabut otot masih dalam keadaan normal dan utuh. Hasil pengamatan histologi $\mathrm{HO}$ bisa dilihat pada Gambar 1.
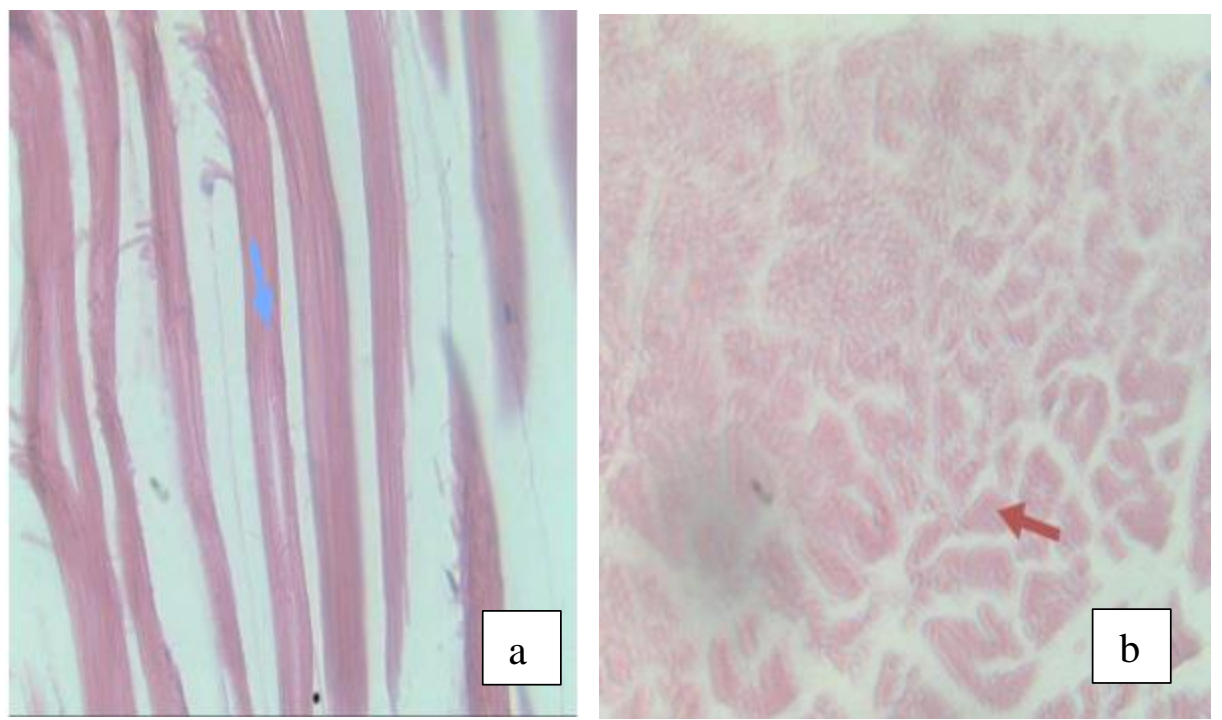

Gambar 1. (b) Lapisan otot lateral (Panah Biru), (b) Lapisan otot lateral (panah merah)

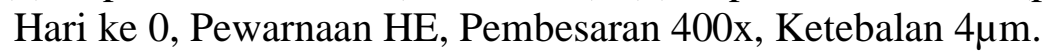

Serabut otot pada hari ke - 0 terlihat kompak dan belum mengalami kerusakan jaringan lapisan otot lateral panah biru A (Gambar 1). Perbesaran gambar serabut otot fase ini dapat dilihat pada panah merah B (Gambar 1) yang menunjukkan serabut otot tersebut menyatu dengan septum yang belum mengalami kerusakan. Pada fase ini eritrosit masih terlihat utuh, sehingga serat pada daging udang masih kompak dan padat belum mengalami kerusakan dan didiagnosis normal (BBAT Jambi dan JICA, 2007).

\section{Uji Histologi Hari ke-3}

Hasil uji histologi hari ke-3 (H-3) Struktur jaringan sudah menunjukkan kemunduran mutu udang putih. Hasil pengamatan histologi pada $\mathrm{H}-3$ bisa dilihat pada Gambar 2. 

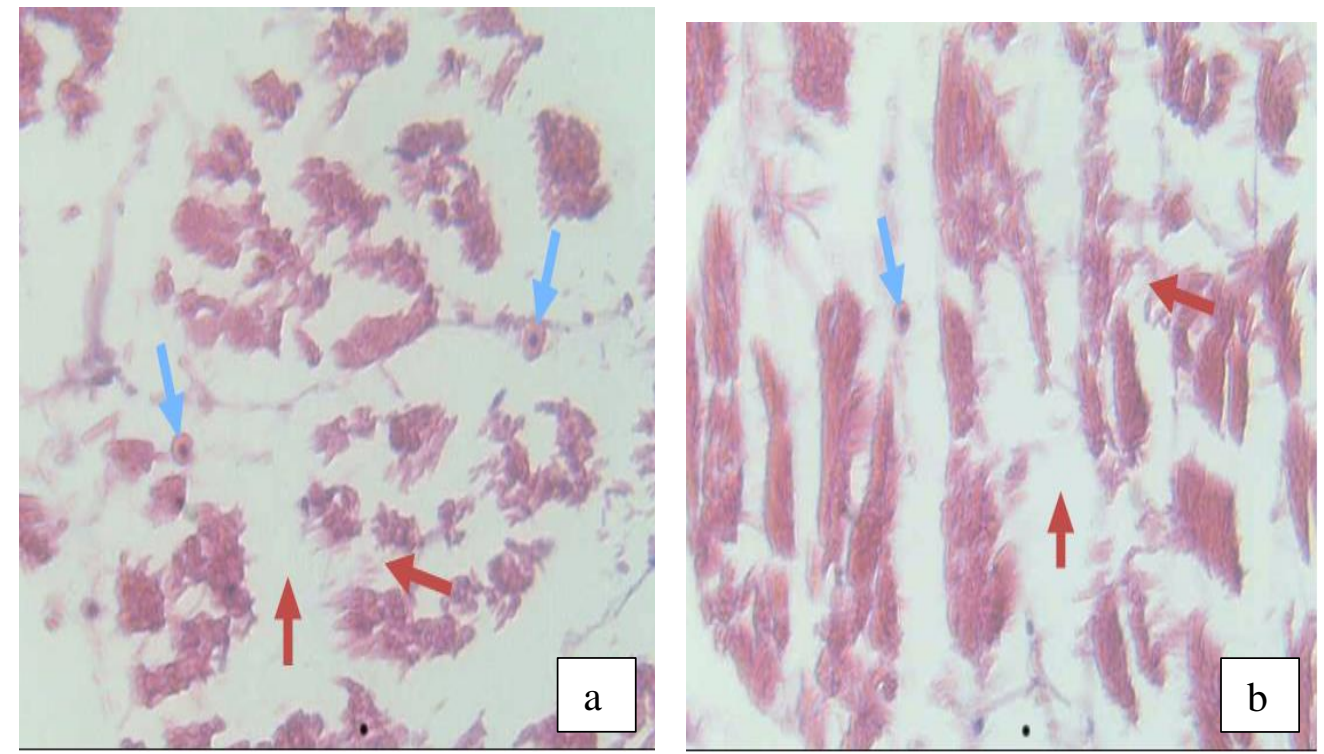

Gambar 2. (a) Eritrosit Panah Biru, (b) Serabut otot (panah merah) hari ke 3, Pewarnaan HE, Pembesaran 400x, Ketebalan $4 \mu \mathrm{m}$.

Awal kemunduran mutu udang terjadi pada bagian tubuh udang yaitu karapas (kulit udang). Infeksi awal munculnya black spot yaitu pada karapas yang kemudian terjadi pelepasan partikel black spot menuju jaringan otot. Jaringan otot pada penyimpanan $\mathrm{H} 3$ panah merah (Gambar 2) menunjukkan terjadinya haemorhagie atau kerusakan eritrosit dan ditemukannya eritrosit diluar pembuluh darah. Uji histologi $\mathrm{H} 3$ juga mengalami degenerasi hialin atau perubahan inti otot (pyknosis) sitoplasma (serabut otot) mengalami hialinasi kondisi dimana sitoplasma lebih mudah pecah dibandingkan dengan serabut yang utuh, namun tidak ditemukan perubahan histologi penyakit menular berbahaya pada sampel udang yang diperiksa.

\section{Uji Histologi Hari ke-6}

Hasil uji histologi hari ke-6 (H6) Struktur jaringan sudah menunjukkan kemunduran mutu udang putih. Hasil pengamatan histologi H6 bisa dilihat pada Gambar 3.

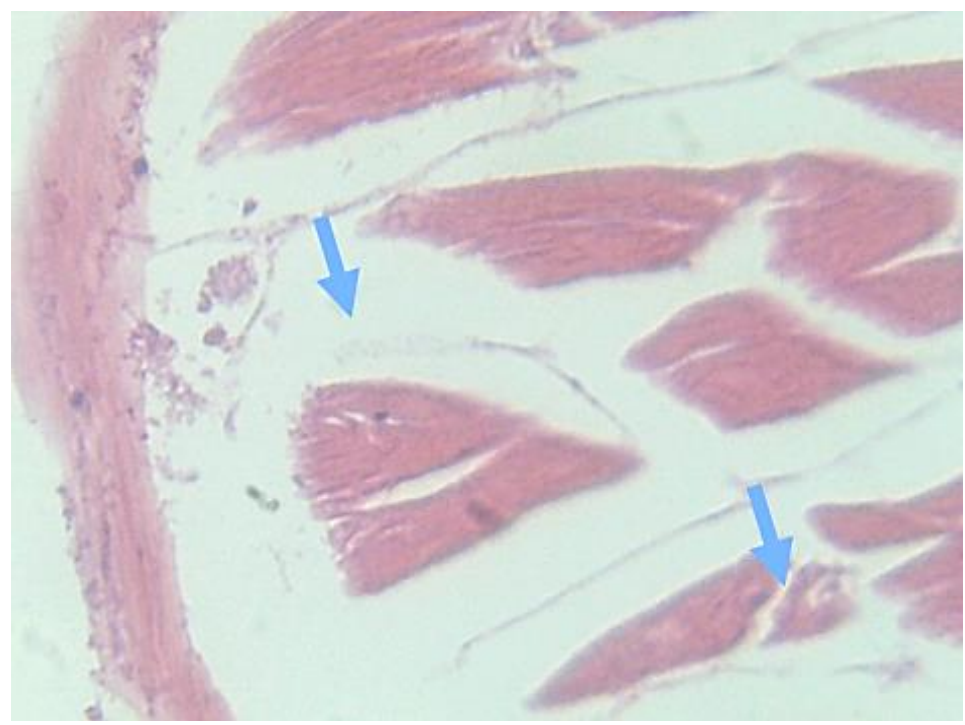

Gambar 3. Lapisan otot lateral (Panah Biru) Hari ke 6, Pewarnaan HE, Pembesaran 400x, Ketebalan $4 \mu \mathrm{m}$. 
Pada sampel H6 terlihat antar serabut otot pada fase rigor mortis mulai mengalami pengerutan (Gambar 3) sehingga mulai terbentuk ruang kosong. Jaringan otot yang mulai mengalami kerusakan pada fase ini disebabkan oleh pengerutan pada serabut otot sehingga menyebabkan mulai adanya ruang kosong yang berwarna putih. Pengerutan pada serabut otot disebabkan oleh kekakuan pada daging udang akibat dari tidak berkontraksinya aktin dan miosin (Morkore et al., 2006). Warna putih pada ruang kosong tersebut di isi oleh parafin saat proses pembuatan preparat histologi. Hal ini sesuai dengan hasil organoleptik yang memiliki tekstur kurang elastis, kurang kompak, dan kurang padat atau daging udang menjadi kaku. Udang yang masih segar mempunyai penampakan cerah dan suram. Keadaan ini terjadi karena belum banyak perubahan biokimiawi. Metabolisme dalam tubuh udang masih berjalan sempurna. Penampakan ini makin lama akan menjadi suram warnanya, karena timbulnya nodanoda hitam (black spot) sebagai akibat berlangsungnya proses biokimiawi lebih lanjut dan berkembangnya mikroba

\section{Uji Histologi Hari ke-9 (H-9}

Hasil uji histologi hari ke-9 (H-9) dapat dilihat pada Gambar 4 sebagai berkut.

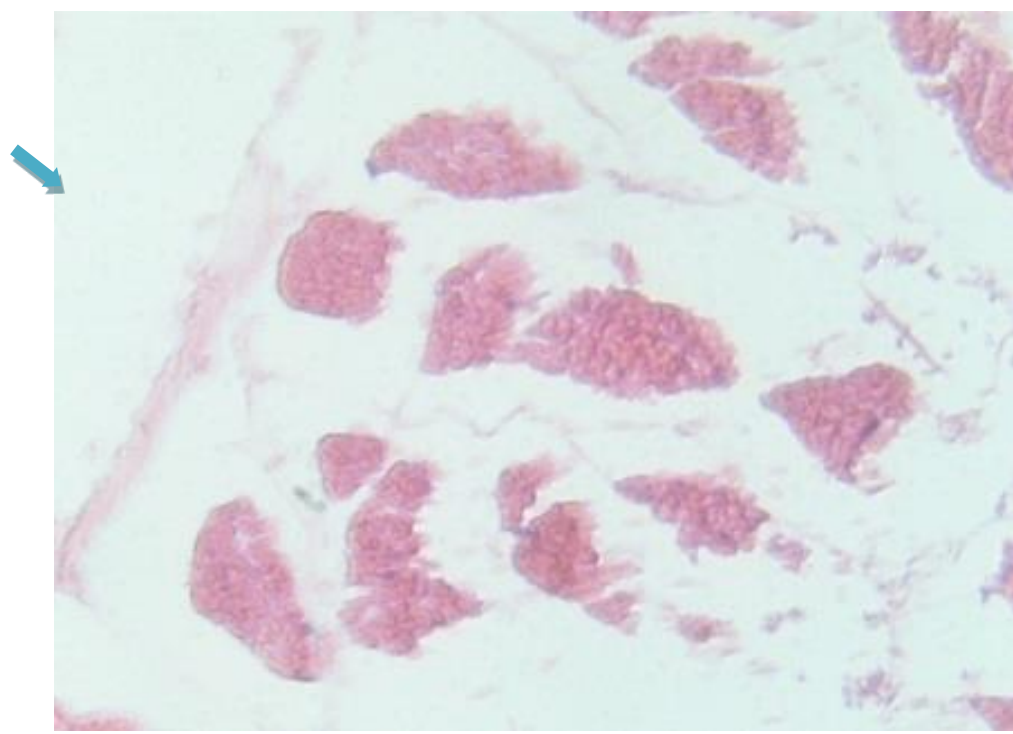

Gambar 4. Lapisan otot lateral (Panah Biru) Hari ke 9, Pewarnaan HE, Pembesaran 400x, Ketebalan $4 \mu \mathrm{m}$.

Fase post rigor terjadi pada penyimpanan $\mathrm{H}-9$ perenggangan yang jelas pada serabut otot Gambar 4. menunjukkan terjadinya kerusakan miomer yang menyebabkan terbentuknya ruang kosong. Kehilangan serat kolagen di miocomata yang menyebabkan pemisahan miomer. Materi padat dalam mitokondria mengalami perluasan akibat lama penyimpanan (Caballero et al., 2009). Menurut Pornrat et al., (2007), disrupsi (perubahan struktur morfologi) pada mitokondria menyebabkan pelepasan enzim ke dalam sarkoplasma. Disrupsi mitokondria terjadi ketika struktur miofibril mengalami degradasi. Serabut otot pada fase ini sudah terpotong-potong atau mengalami kerusakan . Karapas pada fase post rigor terjadi kerusakan akibat waktu penyimpanan. Waktu penyimpanan ini akan berdampak pada aktivitas penyebaran blackspot yang tinggi sehingga menyebabkan terdapat rongga-rongga pada karapas udang.

\section{Uji Histologi Hari ke-12 (H-12)}

Hasil pengamatan histologi $\mathrm{H}-12$ bisa dilihat pada Gambar 5 sebagai berikut. 


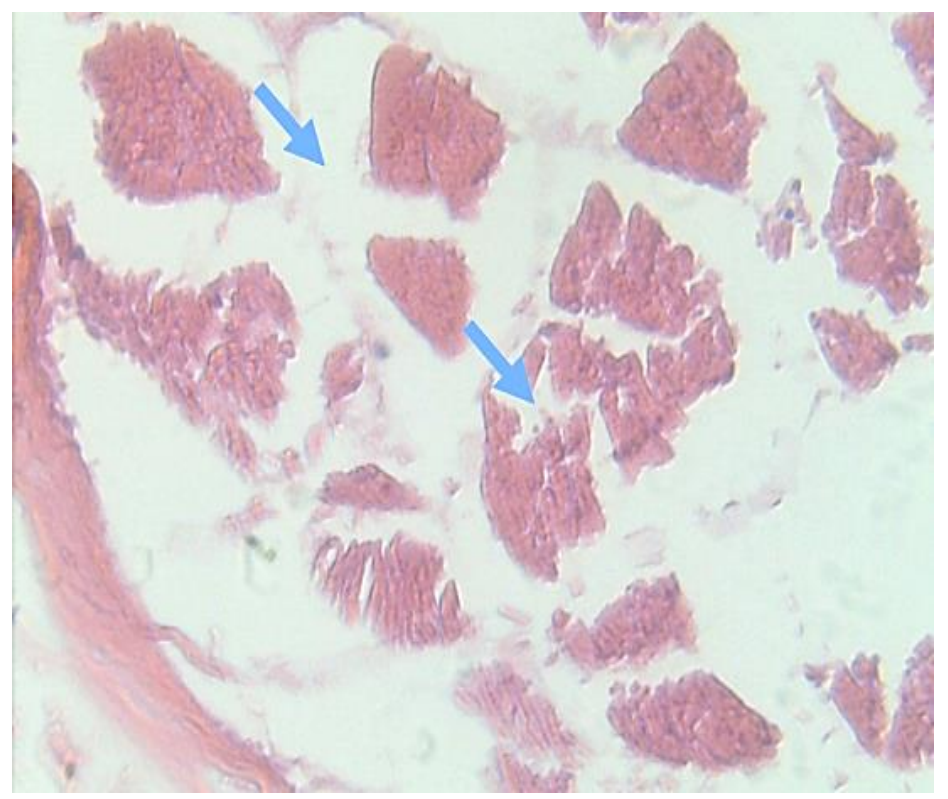

Gambar 5. Lapisan otot lateral (Panah Biru) hari ke12, Pewarnaan HE, Pembesaran 400x, Ketebalan $4 \mu \mathrm{m}$.

Histologi pada jaringan otot pada penyimpanan $\mathrm{H}-12$ sudah mengalami deteriorasi (kebusukan) timbul bau amoniak yang sangat kuat udang menunjukkan adanya perubahan jaringan otot transversal dibandingkan dengan histologi otot udang normal. Hal ini terlihat dengan terjadinya degenerasi, nekrosis dan adanya infiltrasi hemosit pada jaringan otot. Menurut Berata et al., (2015), nekrosis ialah keadaan dimana sel dan jaringan mengalami kematian karena proses degenerasi ireversibel. Sel yang mengalami nekrosis terlihat hancur dan akan hilang atau mati. Tidak ada perubahan histopatologi penyakit menular berbahaya pada sampel yang diperiksa.

\section{KESIMPULAN}

Hasil uji histologi menunjukkan bahwa perubahan konsistensi jaringan tubuh udang sudah mulai mengalami kemunduran mutu pada hari ke-3 dan terus menurun sampai hari ke-12.

\section{SARAN}

Melakukan penelitian lanjutan tentang metode transportasi agar untuk mempertahankan mutu udang lebih baik.
Penelitian tentang suhu transportasi dan penyimpanan yang lebih rendah.

\section{DAFTAR PUSTAKA}

Adiwijaya, D., Supito, I. Sumantri. 2008. Penerapan Teknologi Budidaya Udang Vaname (Litopenaeus vannamei) Semi Intensif Pada Lokasi Tambak Salinitas Tinggi. Media Budidaya Air Payau Perekayasaan. Balai Besar Pengembangan Budidaya Air Payau Jepara. 7:54-72.2003.

Berata I Ketut, Winaya Ida Bagus Oka, Adi Anak Agung Ayu Mirah, Adnyana Ida Bagus Windia. 2015. Patologi Veteriner UmumCetakan ketiga. Penerbit Swasta Nulus. Denpasar.

Caballero MJ, Betancor M, Escring JC, Montero D, Monteros AE, Castro P, Gines R, Izquierdo M. 2009. Post mortem changes produced in the muscle of sea bream (Sparus aurata) during ice storage. $\mathrm{J}$ Aquaculture 291 (3-4): 210-216. 
Gokoglu N, Yerlikaya P. 2008. Inhibition effects of grape seed extracts on melanosis formation in shrimp (Parapenaeus longirostris). International Journal of Food Science and Technology 43: 10041008.

Harjana T. 2011. Histologi. Buku Ajar. Yogyakarta: Fakultas Matematika dan Ilmu Pengetahuan. Universitas Negeri Yogyakarta.

Kementerian Perdagangan Republik Indonesia. 2013. Statistik Perdagangan Luar Negeri, Indonesia.

[KKP]. 2020. Kementrian Kelautan dan Perikanan. Siaran Pers. https://kkp.go.id/artikel/24565 miliki-prospek-ekonomi-tinggikkp-maksimalkan-potensiperikanan-budidaya-di-sumateraselatan. Diakses 30 Desember 2021.

Khaisar, O. 2006. Kandungan Timah Hitam $(\mathrm{Pb})$ dan Kadmium $(\mathrm{Cd})$ dalam Air, Sedimen dan Bioakumulasi Serta Respon Histopatologis Organ Ikan Alualu (Sphyraena barracuda) di Perairan Teluk Jakarta. [Skripsi]. Bogor: Fakultas Perikanan dan Ilmu Kelautan, Institut Pertanian Bogor. Pp 6-8.

Kim J, Marshall MR, Wei C. 2000. poly phenoloxidase. Di dalam : Haard NF dan Simpson BK, editor. Seafood Enzy Mes Utilization and Infuence on Postharvest Seafood Quality. New York (US) : Marcell Dekker,inc . hlm 271-316.

Mulia FJ, Anggraini AY. Perwitasari L. 2018. PKM Wirausaha Pengolahan Produk Berbahan Baku Udang di Kabupaten
Banyuasin Provinsi Sumatera Selatan. Prosiding SemNas Avoer 10. 31 Oktober. 2018. Hal : 884890.

Nurjanah, Abdullah A, Kustiariyah. 2011. Pengetahuan dan Karakteristik Bahan Baku Hasil Perairan. Bogor (ID): IPB Press.

Panigoro NI, Astuti M, Bahnan DC, Prayuda, Salfira K. Wakita. 2007. Teknik Dasar Histologi dan Atlas Dasar-Dasar Histologi Ikan. Balai Budidaya Air Tawar (BBAT) Jambi dan Japan International Cooporation Agency (JICA).

Pornrat S, Sumate T, Rommance S, Sumolaya K, Kerr WL. 2007. Changes in thde ultrastructure and texture of prawn muscle (Macrobrachuim rosenbergii) 20during cold storage. LWT-Food Science and Technology40:17471754.

Prasetyani T. 2017. Gambaran Mikroskopis Histologi Bloksel Efusi Pleura dengan Menggunakan Fiksasi Alkohol $70 \%$ dan NBF $10 \%$ pada Pewarnaan HE. Karya Tulis Ilmiah. Universitas Muhammadiyah Semarang.

Sugiono. 2018. Metode Penelitian Kuantitatif. Penerbit Alfabeta. Bandung.

Suwetja IK. 2011. Biokimia Hasil Perikanan. Jakarta (ID): Media Prima Aksara.

Utari SA. 2014. Kemunduran Mutu Udang Putih: Organoleptik, blackspot, histologist, dan enzimatis [skripsi]. Bogor (ID): Fakultas Perikanan dan Ilmu Kelautan, Institut Pertanian Bogor. 
Uji histologi udang putih (Liptopenaeus vannamei) selama penyimpanan... Dion Mayodra et al., Jurnal Ilmu-ilmu Perikanan dan Budidaya Perairan Vol. 16 (2). Desember 2021:95-102

Zamorano JP, Alvarez OM, Montero P,

Guillen 2009.

Characterisation and tissue

distribution of polyphenol

oxidaase of deepwater pink shrimp

(Parapenaeus longirostris). Food

Chemistry 112: $104-111$. 